\title{
Studies on the Pathogenesis of Acute Inflammation
}

\author{
IX. THE INFLUENCE OF HYPEROSMOLALITY SECONDARY \\ TO HYPERGLYCEMIA UPON THE ACUTE INFLAMMATORY RESPONSE \\ INDUCED BY THERMAL INJURY TO EAR CHAMBERS OF RABBITS
}

\author{
Sterling K. Ainsworth and Fred Allison, Jr. \\ From the Departments of Medicine and Microbiology, University Medical \\ Center, Jackson, Mississippi 39216
}

\begin{abstract}
A в S TR A C T The inflammatory reaction induced in ear chambers of rabbits by heat injury was studied in nondiabetic animals made hyperglycemic with continuous infusions of glucose. Hypertonic solutions of glucose administered intravenously to rabbits induced the following triad: hyperglycemia, hyperosmolality, and metabolic lactic acidosis. It was found that relatively short periods of this metabolic abnormality were associated with a significant reduction in the intensity of the inflammatory reaction.

There was no evidence microscopically of circulatory impairment within ear chambers ; and since neither arterial hypotension nor oxygen deficit was recorded during experiments, it appeared most likely that decreased leucocytic margination per se best explained the inhibited exudative response.

Hyperglycemia seemed the dominant factor responsible for this anti-inflammatory effect. It was found subsequently that hyperglycemia and hyperosmolality without metabolic acidosis impaired cellular exudation just as well.
\end{abstract}

\section{INTRODUCTION}

There is evidence from studies in animals to indicate that poorly controlled diabetes mellitus increases susceptibility to infection by bacterial and fungal pathogens (1-3). Firm proof that the same is true for human beings is lacking, although there are substantial clinical

This work was presented in part to the meeting of the Federated Societies, 16 April 1966, Atlantic City, N. J.

Dr. Ainsworth's present address is the University of Alberta, Department of Biochemistry, Edmonton, Alberta, Canada.

Dr. Allison's present address is the Louisiana State University Medical Center, Department of Medicine, New Orleans, La., 70112.

Received for publication 12 May 1969. indications that lead one to believe that these infections are inadequately contained by diabetic patients (4). Recent studies reported from several laboratories showed that polymorphonuclear granulocytes (PMNG) recovered from venous blood of diabetic animals and humans function as well as cells obtained from control donors $(2,5-7)$. In contrast, Drachman, Root, and Wood suggested that cells contained in exudates with modest increases of osmolality from either healthy or nonketotic diabetic rats exhibited a depressed phagocytic ability both in vivo and in vitro. Their evidence suggested that hyperglycemia might be the critical parameter that enhanced the susceptibility of diabetics to infection (2).

Other lines of evidence also suggest that the osmolality of blood may have important bearing upon the vigor and efficiency of the inflammatory response mobilized in the papillary region of the kidney where flow of blood is substantially slower than in the renal cortex $(8,9)$. In addition, the renal medullary tissues are probably low in $\mathrm{pH}$, relatively anoxic, and have a higher interstitial osmolality than cortical tissue of the kidney (10). There is also cinephotomicrographic evidence that the rheologic properties of the cellular elements of the blood stream are altered by physiochemical changes of extravascular fluid within these areas of high interstitial osmolality (11). It is remarkable that no systematic effort has been made, to the best of the authors' knowledge, to determine in vivo whether the osmolality attending hyperglycemia in itself will modify the exudative aspects of acute inflammation in extrarenal loci. There is evidence, however, that hyperglycemia complicated by ketoacidosis in uncontrolled diabetes mellitus is associated with an impaired inflammatory reaction $(3-5,12)$.

From the narrative that follows it can be seen that attempts were made to correlate the intensity of inflammation seen within heat damaged tissue of ear chambers with the degree of hyperglycemia and hyperosmolality 
TABLE I

Determination of Maximal Sublethal Amount of Hypertonic Glucose Solution for 4-hr Infusions to Rabbits

\begin{tabular}{|c|c|c|c|c|c|c|c|}
\hline \multirow{3}{*}{$\begin{array}{c}\text { Weight } \\
\text { of } \\
\text { subject }\end{array}$} & \multirow{3}{*}{$\begin{array}{c}\text { Amount } \\
\text { of } \\
\text { glucose }\end{array}$} & \multirow{3}{*}{$\begin{array}{l}\text { Total } \\
\text { glucose } \\
\text { admin- } \\
\text { istered }\end{array}$} & \multicolumn{4}{|c|}{ Serum values } & \multirow[b]{3}{*}{ Died } \\
\hline & & & \multicolumn{2}{|c|}{ Glucose } & \multicolumn{2}{|c|}{ Serum osmolality } & \\
\hline & & & $\begin{array}{c}\text { Before } \\
\text { infusion }\end{array}$ & $\begin{array}{c}\text { After } \\
\text { infusion }\end{array}$ & $\begin{array}{c}\text { Before } \\
\text { infusion }\end{array}$ & $\begin{array}{c}\text { After } \\
\text { infusion }\end{array}$ & \\
\hline$k g$ & $g / k g$ & $g$ & $\mathrm{mg} / 100 \mathrm{ml}$ & $m g / 100 \mathrm{ml}$ & $\mathrm{mOsm} / \mathrm{kg}$ & $\mathrm{mOsm} / \mathrm{kg}$ & \\
\hline 3.2 & 25.3 & 81.2 & 97 & 3640 & 300 & 418 & $\mathrm{X}$ \\
\hline 3.6 & 20.0 & 72.0 & 97 & 1014 & 290 & 385 & $\mathrm{X}$ \\
\hline 3.1 & 25.6 & 78.7 & 65 & 1350 & 296 & 347 & $X$ \\
\hline 3.7 & 13.1 & 48.6 & 136 & 600 & 293 & 312 & \\
\hline 3.2 & 16.1 & 51.6 & 120 & 888 & 288 & 335 & \\
\hline 3.9 & 15.5 & 54.2 & 105 & 885 & 296 & 331 & \\
\hline 3.6 & 15.2 & 54.9 & 108 & 867 & 294 & 324 & \\
\hline 3.2 & 18.9 & 60.4 & 88 & 876 & 315 & 351 & \\
\hline
\end{tabular}

induced in nondiabetic rabbits. An unexpected complication of the procedure was the occurrence of uncompensated metabolic acidosis, nonketotic in origin, associated with hyperglycemia and hyperosmolality. The metabolic acidosis associated with glucose infusions as reported elsewhere was found to be accompanied by high levels of lactate. In these studies $\mathrm{Po}_{2}$ and $\mathrm{O}_{2}$ saturation determinations failed to show evidence of significant ischemia even though in most instances it is thought that lactic acidosis stems from tissue hypoxia. Furthermore, measurement of systolic blood pressure and direct observation of the capillary bed of the ear chamber substantiated the fact that the peripheral circulation was not impaired by the glucose infusions. ${ }^{1}$

It was found in the present studies that the adherence of leucocytes to damaged endothelium in ear chambers was impaired during periods of the metabolic acidosis that accompanied serum hyperosmolality and that the exudation of blood-borne cells was reduced in similar fashion. Correction of acidosis by use of an organic buffer given with glucose proved that a change of hydrogen ion concentration was not the crucial parameter for inhibition of inflammation under these experimental conditions.

\section{METHODS}

Ear chambers. A modification of the Sandison-Clark rabbit ear chamber equipped with a central platinum wire heat conductor was used for the study of acute inflammatory reactions induced by burn injury (13). Ear chambers were used only if the tissue appeared mature, free of evidence of an inflammatory reaction, and had a thickness of 20-50 $\mu$.

Rabbits. A cross between New Zealand white and English lop rabbits of either sex was obtained locally and maintained under carefully. controlled laboratory conditions. Weights ranged from 2.8 to $3.9 \mathrm{~kg}$.

${ }^{1}$ Ainsworth, S. K., and F. Allison, Jr. In preparation.
Glassziarc. All glassware was siliconized with Siliclad (Clay-Adams, Inc., New York) and rendered pyrogen-free by routine washing procedures followed by dry sterilization at $170^{\circ} \mathrm{C}$ for $2 \mathrm{hr}$.

Solutions and reagents. An aqueous solution which contained $25 \mathrm{ml}$ of sterile, nonpyrogenic, $50 \%$ glucose and 25 $\mathrm{ml}$ of sterile, nonpyrogenic, $5 \%$ glucose (Baxter Laboratories, Inc., Morton Grove, Ill.) was prepared for the 10 acute $(4 \mathrm{hr})$ experiments. Each rabbit received intravenously $200 \mathrm{ml}$ of this solution which contained $55 \mathrm{~g}$ of glucose. For 15 chronic $(24 \mathrm{hr}$ ) experiments, $300 \mathrm{ml}$ of sterile, nonpyrogenic, $50 \%$ glucose solution (150 g of glucose) was administered intravenously over $24 \mathrm{hr}$.

The glucose solutions were given at a constant rate with a Harvard infusion/withdrawal multispeed transmission pump (Harvard Apparatus Co., Inc., Dover, Mass.) by way of a polyethylene tube installed in the marginal vein of the ear opposite that used for observation. For acute experiments $(4 \mathrm{hr})$ the glucose solution was infused at a rate of 0.764 $\mathrm{ml} / \mathrm{min}$.

Injury of car chamber. Tissue covering the observation table of ear chambers was injured by heat applied to the platinum wire conductor from an electric pencil previously warmed for $10 \mathrm{~min}$ to achieve a constant temperature (13). For the acute $(4 \mathrm{hr})$ experiments tissue within the ear chamber was injured by heat $1 \mathrm{hr}$ after infusions were started. In the chronic $(24 \mathrm{hr})$ experiments the tissue was burned 4-5 hr after infusions were begun. After injury, observations were made continuously from 4 to $24 \mathrm{hr}$ and intermittently thereafter as indicated.

Chemical determinations. Serum glucose levels in venous blood samples were determined by automated techniques. Osmolality measurements were made with a Model G Fiske osmometer (Fiske Association, Inc., Uxbridge, Mass.). Blood $\mathrm{pH}$, lactic acid, and electrolytes were monitored as described previously. ${ }^{1}$

Photographic procedure. A $35 \mathrm{~mm}$ Leitz camera equipped with a Microibso attachment was used to document microscopic events in expermients with Kodak Type B EHB-135 high speed Ektachrome film. The film was processed with Kodak Ektachrome film processing kits, E-2 and E-3. The 35-mm transparencies were printed by Eastman Kodak Co., Rochester, N. Y. Cinephotomicrographs of experiments were recorded with a $16 \mathrm{~mm}$ camera as described previously (13). 


\section{RESULTS}

\section{Acute experiments}

Lethality of glucose. Eight rabbits without ear chambers were used to determine the lethality of 4-hr infusions of glucose. When more than $70 \mathrm{~g}$ of glucose was given, blood glucose levels exceeded $1000 \mathrm{mg} / 100 \mathrm{ml}$ at the end of the infusion. These rabbits died during or immediately after the infusion (Table I). Animals given between 50 and $60 \mathrm{~g}$ of glucose (13-18 $\mathrm{g} / \mathrm{kg}$ body weight) over $4 \mathrm{hr}$ did not have serum glucose levels that were as high, and the recipients survived. Hence. it was decided to infuse animals with $13.0-16.0 \mathrm{~g}$ of glucose $/ \mathrm{hr}$ for $4 \mathrm{hr}$ for a total of $52-64.0 \mathrm{~g}$. It was also found that when this amount of glucose was given hyperglycemia ensued and serum osmolalities were moderately elevated but not to the extent encountered with fatal infusions (Table I). Metabolic acidosis with high blood lactate concentrations was found to parallel in general the severity of serum hyperosmolality. ${ }^{1}$

Results of ear chamber studies. Administration of glucose for $4 \mathrm{hr}$ failed to influence the dynamics of the circulation within uninjured rabbit ear chambers. There was no evidence that erythrocytes aggregated into rouleaux, that platelet clumping was instigated, or that leucocytes became sticky and adhered to each other or to

TABLE II

Effect of Infusions of Hypertonic Glucose upon Sticking and Diapedesis of PMNG in Heat Damaged Ear Chambers of Rabbits Microscopic Findings after Injury*

\begin{tabular}{|c|c|c|c|c|c|c|c|c|c|c|}
\hline \multirow[b]{2}{*}{$\begin{array}{c}\text { Rabbit } \\
\text { No. }\end{array}$} & \multicolumn{2}{|c|}{$3 \mathrm{hr}$} & \multicolumn{2}{|c|}{$6 \mathrm{hr}$} & \multicolumn{2}{|c|}{$9 \mathrm{hr}$} & \multicolumn{2}{|c|}{$12 \mathrm{hr}$} & \multicolumn{2}{|c|}{$24 \mathrm{hr}$} \\
\hline & $\begin{array}{l}\text { Stick- } \\
\text { ing }\end{array}$ & $\begin{array}{c}\text { Diape- } \\
\text { desis }\end{array}$ & $\begin{array}{l}\text { Stick- } \\
\text { ing }\end{array}$ & $\begin{array}{c}\text { Diape- } \\
\text { desis }\end{array}$ & $\begin{array}{l}\text { Stick- } \\
\text { ing }\end{array}$ & $\begin{array}{c}\text { Diape- } \\
\text { desis }\end{array}$ & $\begin{array}{l}\text { Stick- } \\
\text { ing }\end{array}$ & $\begin{array}{c}\text { Diape- } \\
\text { desis }\end{array}$ & $\begin{array}{c}\text { Stick- } \\
\text { ing }\end{array}$ & $\begin{array}{c}\text { Diape- } \\
\text { desis }\end{array}$ \\
\hline
\end{tabular}

A. 24-hr controls

\begin{tabular}{|c|c|c|c|c|c|c|c|c|c|c|}
\hline $15-3$ & $++t$ & ++ & $++t$ & ++ & $+t+$ & +++ & ++ & $+t+$ & + & $+t+$ \\
\hline $17-2$ & +++ & ++ & ++ & ++ & $+t$ & $+t$ & ++ & ++ & 0 & $+t$ \\
\hline $16-1$ & + & + & $+t+$ & ++ & $++t$ & $+t+$ & $+t$ & $+t+$ & + & \\
\hline $24-2$ & $++t$ & +++ & ++ & $++t$ & + & +++ & $+t+$ & $+t+$ & ++ & $+t+$ \\
\hline $26-0$ & $+t+$ & ++ & $+t+$ & +++ & ++ & $++t$ & $+t+$ & $+t+$ & ++ & \\
\hline
\end{tabular}

B. 4-hr experiments

\begin{tabular}{|c|c|c|c|c|c|c|c|c|c|}
\hline $19-3$ & + & + & 0 & + & 0 & + & 0 & + & 0 \\
\hline $16-4$ & + & + & + & + & 0 & + & 0 & + & 0 \\
\hline $17-5$ & 0 & 0 & + & 0 & + & 0 & 0 & 0 & 0 \\
\hline $19-8$ & + & + & + & $+t$ & + & ++ & + & ++ & + \\
\hline $17-9$ & 0 & 0 & 0 & 0 & + & + & + & + & + \\
\hline
\end{tabular}

C. 24-hr experiments

$\begin{array}{rrrrrrrrrrr}24-1 & + & + & + & + & + & + & + & + & 0 & + \\ 22-0 & 0 & 0 & 0 & 0 & + & + & + & + & + & + \\ 20-4 & 0 & 0 & + & 0 & + & + & + & + & 0 & + \\ 21-3 & ++ & + & + & + & + & + & 0 & + & ++ & ++ \\ 26-3 & + & 0 & 0 & 0 & + & 0 & + & 0 & 0 & 0 \\ 25-5 & + & + & ++ & ++ & 0 & ++ & 0 & ++ & 0 & ++\end{array}$

D. Buffered experiments

$\begin{array}{lllllllllll}1 & + & 0 & 0 & 0 & 0 & 0 & 0 & 0 & 0 & 0 \\ 2 & + & 0 & + & 0 & + & + & + & + & 0 & + \\ 3 & 0 & 0 & 0 & 0 & 0 & 0 & 0 & 0 & 0 & 0 \\ 4 & + & + & + & + & + & + & + & + & 0 & 0 \\ 5 & + & + & + & + & 0 & + & 0 & + & 0 & + \\ 6 & + & + & + & + & 0 & + & 0 & + & 0 & +\end{array}$

* Preinjury-All ear chambers were essentially devoid of sticking, diapedesis, and hemorrhage before thermal injury was initiated. Due to the large number of experiments performed in the 4- and 24-hr studies, this table has been used to demonstrate results at various time intervals from six animals.

$\ddagger 0=$ none, $+=$ light,$++=$ moderate, $+++=$ heavy. 
vascular endothelium as a result of the infusion. Blood pressures were determined with a Grant-Rothchild capsule applied to the central artery of the ear, and there was no evidence of a substantial change during the time infusions were in progress.

The microcirculatory events that follow burn injury to rabbit ear chambers have been described in detail previously (13). This model has been systematically observed by both authors several hundred times in untreated animals; these studies served as our control (see Table II). Burn injury to ear chambers produces an acute inflammatory reaction that is not only predictable but reproducible within the limits of a biological system.

It will be recalled that in this series of studies, ear chambers were burned one hour after the glucose infusions were initiated. The effects of short episodes of hyperglycemia, hyperosmolality, and metabolic acidosis upon the acute inflammatory response induced by thermal burn were limited to two distinct and decisive aspects of the reaction. First, it was observed repeatedly that the leucocytic sticking reaction was substantially less in animals receiving glucose (see Table II). Continuous observation of the reaction confirmed the fact that the margination of PMNG remained at low levels not only during the $4 \mathrm{hr}$ of infusion but for the entire 24 $\mathrm{hr}$ of study. Thus when documented photographically there were far fewer PMNG to be found as exudate than were recorded in chambers of untreated animals. A second aspect worthy of note was the fact that after glucose was infused there was less perivascular hemorrhage to be found about static vessels located on the perimeter of the burned tissue. This was so even though vasodilation and the flow of blood within tissue of ear chambers of the metabolically abnormal animals appeared just as prominent as was recorded for damaged chambers of untreated rabbits. The net result of the glu- cose infusions amounted to a significant reduction in the number of blood cells of all types that by diapedesis migrated into the damaged ear tissue.

\section{Chronic experiments}

Since the elevated carbohydrate levels produced during the 4-hr studies simulated only briefly one aspect of the abnormal metabolism of poorly controlled diabetes mellitus, it was of interest to find whether a sustained state of hyperglycemia, hyperosmolality, and metabolic acidosis would alter either the capillary dynamics of uninjured ear chambers or the acute inflammatory response generated by heat.

Lethality of glucose. It was found that administration of more than $200 \mathrm{~g}$ of glucose during $24 \mathrm{hr}$ led to blood glucose levels in excess of $1000 \mathrm{mg} / 100 \mathrm{ml}$. Death always occurred during or immediately after the infusion. On the other hand, animals given $150 \mathrm{~g}$ of glucose during $24 \mathrm{hr}$ ( $40-46 \mathrm{~g} / \mathrm{kg}$ body weight) developed more modest elevations of blood glucose, and they almost always survived (Table III). Therefore, it was decided to infuse the rabbits continuously with glucose at the rate of $25 \mathrm{~g}$ every $4 \mathrm{hr}$ for a total of $150 \mathrm{~g}$. It may be seen that these levels of hyperglycemia also caused metabolic acidosis (Chart 1) and a concomitant elevation of serum osmolality (Table III).

Results of ear chamber studies. When a $50 \%$ glucose solution was given continuously for $24 \mathrm{hr}$, the flow of blood decreased for brief periods in the ear chambers of some animals. Occasionally these episodes of vasocontriction led to rouleaux formation and stasis of blood flow in a few channels but outside stimuli were believed tu be responsible for their occurrence. It should be emphasized, however, that no consistent alteration was found in flow of blood or dispersion of the intravascular cellular elements during the $24 \mathrm{hr}$ of observation. No leakage of red blood cells with formation of hemorrhage

TABLE III

Determination of Maximal Sublethal Amount of Hypertonic Glucose Solution for 24-hr Infusions to Rabbits

\begin{tabular}{|c|c|c|c|c|c|c|c|}
\hline \multirow{3}{*}{$\begin{array}{l}\text { Weight } \\
\text { of } \\
\text { subject }\end{array}$} & \multirow{3}{*}{$\begin{array}{c}\text { Amount } \\
\text { of } \\
\text { glucose }\end{array}$} & \multirow{3}{*}{$\begin{array}{l}\text { Total } \\
\text { glucose } \\
\text { admin- } \\
\text { istered }\end{array}$} & \multicolumn{4}{|c|}{ Serum values } & \multirow[b]{3}{*}{ Died } \\
\hline & & & \multicolumn{2}{|c|}{ Glucose } & \multicolumn{2}{|c|}{ Serum osmolality } & \\
\hline & & & $\begin{array}{c}\text { Before } \\
\text { infusion }\end{array}$ & $\begin{array}{c}\text { After } \\
\text { infusion }\end{array}$ & $\begin{array}{c}\text { Before } \\
\text { infusion }\end{array}$ & $\begin{array}{c}\text { After } \\
\text { infusion }\end{array}$ & \\
\hline$k g$ & $g / k g$ & $g$ & $m g / 100 m l$ & $m g / 100 m l$ & $\mathrm{mOsm} / \mathrm{kg}$ & $\mathrm{mOsm} / \mathrm{kg}$ & \\
\hline 3.4 & 80.4 & 276 & 134 & 2520 & 292 & 403 & $\mathrm{X}$ \\
\hline 3.4 & 60.0 & 204 & 117 & 1400 & 299 & 383 & $\mathrm{X}$ \\
\hline 3.2 & 46.6 & 150 & 116 & 900 & 292 & 380 & \\
\hline 3.6 & 41.7 & 150 & 131 & 725 & 293 & 318 & \\
\hline 3.4 & 44.4 & 150 & 128 & 552 & 294 & 336 & \\
\hline 3.8 & 42.1 & 150 & 132 & 495 & 296 & 310 & \\
\hline
\end{tabular}




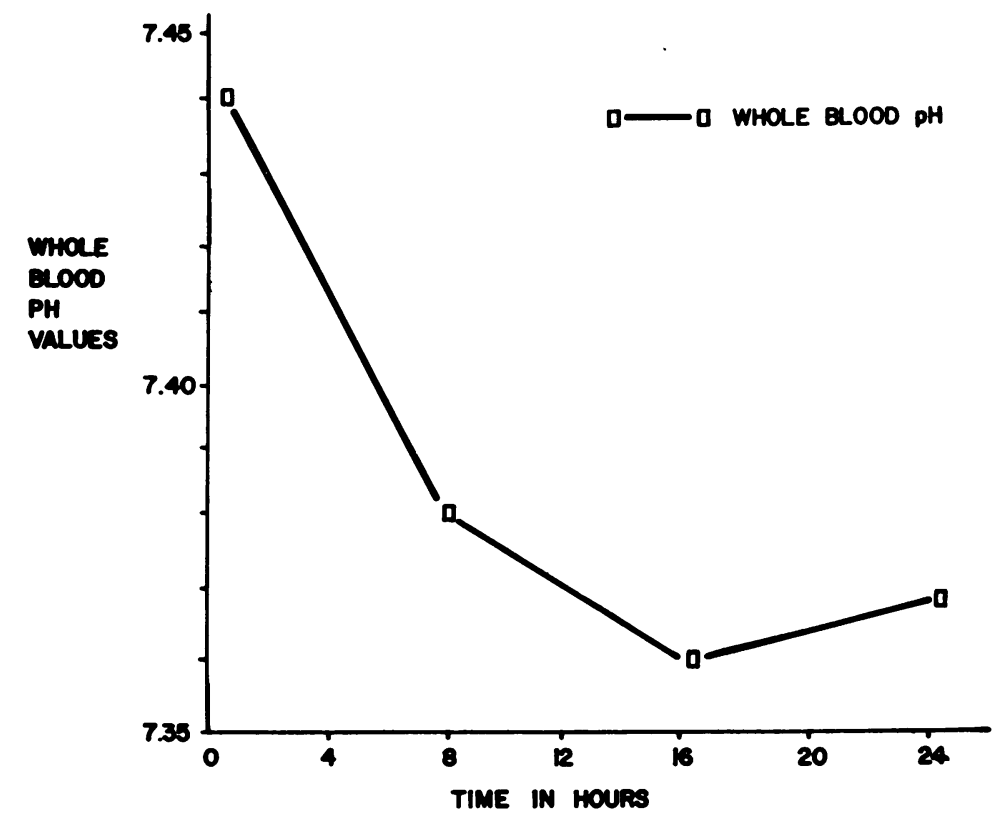

Chart 1 Serial determinations of arterial blood $\mathrm{pH}$ in rabbits during 24 hr of $50 \%$ glucose infusions. Each point represents mean vaiues of 30 animals tested at each time interval.

was seen. Furthermore, there was no evidence to suggest development of platelet plugs, erythrocytic clumps, or sticking of leucocytes to vascular endothelial cells during protracted infusion of glucose solution. At times the blood appeared hyperchromatic during the times of infusion but this was an inconstant event.

Thermal injury was induced $4 \mathrm{hr}$ after the infusion was begun. No immediate difference in flow of blood within ear chambers was observed between the metabolically deranged and the normal animals. The circulation that bordered burned tissue of the chamber became reestablished after a brief episode of vasoconstriction that lasted from 1 to $5 \mathrm{~min}$. Vasodilation developed in the injured chambers of hyperglycemic animals exactly as was found in the untreated animals, i.e., within 30 min after injury, arteriolar dilation was striking and the total flow of blood was substantially greater than before injury.

Sticking of leucocytes. The sticking of leucocytes to vascular endothelium developed in the ear chambers of hyperglycemic animals approximately $15 \mathrm{~min}$ after thermal burn. This was in keeping with results reported earlier for the sticking of PMNG in ear chambers injured by heat in untreated animals (13). However, in contrast to control animals (Figs. 1-3), the sticking reaction was not as heavy in hyperglycemic animals (Figs. 4-6). In most experiments only a few cells were noted to be sticking to vascular endothelium within 9 to $12 \mathrm{hr}$ (Fig. 5), and no sticking was to be found in a few chambers by $12 \mathrm{hr}$. In other experiments very light sticking of white blood cells was observed during the entire $24 \mathrm{hr}$ of study. Overall, the adhesion of leucocytes to vascular endothelium was substantially lighter within the ear chambers of metabolically abnormal animals studied for $24 \mathrm{hr}$ when compared to the acute inflammatory response evoked in untreated rabbits.

As expected, the migration of white blood cells into perivascular connective tissue began soon after intravascular sticking was first detected. Cellular accumulation was more noticeable about vessels nearest the lesion and paralleled in general the intensity of leucocytic sticking. It was not surprising to note, however, that diapedesis was reduced, and hence, the entire exudative cellular response was seen to be impaired beginning with the stage of PMNG sticking to the emigration and accumulation of cells within injured ear chamber tissue of hyperglycemic rabbits (compare Figs. 3 and 6).

Hemorrhages about small injured vessels became clearly visible in the chamber tissues of untreated rabbits from 6 to $18 \mathrm{hr}$ after thermal burn and covered a large part of the inner or central chamber area. This aspect of the inflammatory reaction was reduced in the ear chambers of hyperglycemic animals; and because hemorrhage was not observed until as late as 18-24 hr. infiltration of the tissue interstices by red blood cells was substantially lessened. In addition, it was noted that the connective tissue of animals infused with glucose appeared less opaque and seemed to contain less edema fluid. 


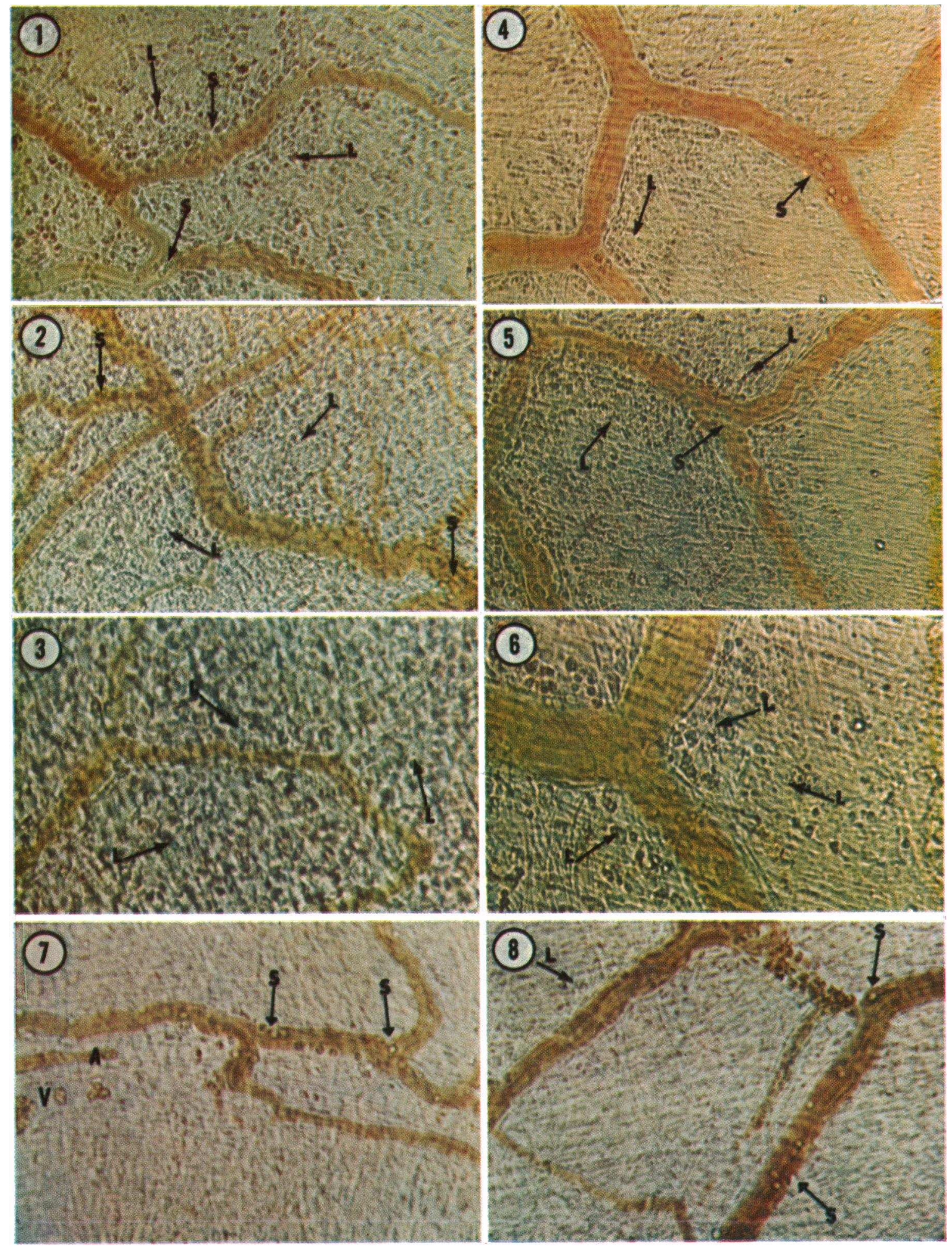


The effect of hyperosmolality without acidosis on inflammation

Next, we sought to identify and define separately the effect of metabolic acidosis and serum hyperosmolality upon the inflammatory response. Concentrated solutions of $\mathrm{NH}_{4} \mathrm{Cl}$ and $\mathrm{HCl}$ were given intravenously for $4 \mathrm{hr}$ into rabbits in order to study the effects of acidosis on inflammation without hyperosmolality. These agents produced metabolic acidosis easily enough but proved difficult to regulate since most animals expired suddenly and unpredictably after the desired level of acidosis was reached. Arterial $\mathrm{pH}$ values in the range of 7.20 were found to be irreversible in these recipients. Serum osmolality values were also increased. The ear chambers of four animals made acidotic and hyperosmotic with ammonium chloride were injured by heat. The inflammatory responses encountered were substantially less than in controls and were identical to the reaction found after infusions of hypertonic glucose. From this then it seemed that an excess of glucose was not required for suppression of inflammation. This approach was discarded when it was found to be impossible to avoid induction of hyperosmolality.

Our attention then turned to attempts to produce hyperosmolality with intravenous glucose without an associated metabolic acidosis. Initially it was found that sodium bicarbonate was unsatisfactory for use in neu- tralizing glucose induced acidosis as animals often died suddenly after large amounts of bicarbonate were given. Trial of the organic compound 2-amino-2-(hydroxymethyl)-1,3-propanediol (THAM) (Abbott Laboratories, North Chicago, Ill.) proved to be more effective than sodium bicarbonate in controlling metabolic acidosis produced by hypertonic glucose. It was found that $10 \mathrm{ml}$ of a $0.6 \mathrm{M}$ solution of THAM mixed with $200 \mathrm{ml}$ of $27.5 \%$ glucose solution could be infused safely at the rate of $0.75 \mathrm{ml} / \mathrm{min}$ for $4 \mathrm{hr}$. This mixture consistently produced hyperglycemia and serum hyperosmolality with no major change in arterial $\mathrm{pH}$ values.

Next, six acute $(4 \mathrm{hr})$ ear chamber experiments using THAM neutralized glucose solutions were performed. In each instance, hyperosmolality of serum was found with no evidence of metabolic acidosis. The subsequent leucocytic sticking reaction with diapedesis into perivascular connective tissue approached results found in studies without neutralized glucose, i.e., both events were materially reduced. (Figs. 7 and 8 illustrate the sticking and exudative response 2 and $4 \mathrm{hr}$ after thermal injury.) Leucocytic and platelet thrombi were not evident, whereas, this was a common response in injured controls. These results were virtually identical to data noted previously in studies when hyperglycemia, hyperosmolality, and acidosis prevailed. Examination $24 \mathrm{hr}$ later revealed that leucocytic exudation was decreased.

Figures 1-3 illustrate the robust inflammatory reaction recorded in ear chambers of untreated or control animals. Fig. 1. Untreated rabbit. Brisk sticking of leucocytes within the venule is visible $(\mathrm{S})$. Moderate infiltration of connective tissue by polymorphonuclear granulocytes (L) was apparent $3 \mathrm{hr}$ after thermal injury. $\times 200$. Fig. 2 . Untreated rabbit. Note heavy infiltration of connective tissue by PMNG (L). The large numbers of PMNG (L) give the tissue a granular appearance. A vigorous sticking reaction (S) persisted $9 \mathrm{hr}$ after the thermal injury. $\times 200$. Fig. 3. Untreated rabbit. The heavy exudation of PMNG (L) that occurred within $24 \mathrm{hr}$ after thermal injury can best be seen at higher magnification. These cells (L) are still motile and densely packed within the connective tissue. $\times 400$.

FIGURES 4-6 show the mild inflammatory reaction encountered in the ear chambers of nondiabetic animals made hyperglycemic and acidotic for $24 \mathrm{hr}$. Fig. 4. Hyperglycemic acidotic rabbit. A representative reaction $3 \mathrm{hr}$ after injury. Note that even though margination of PMNG was present $(\mathrm{S})$, transient sticking predominated at this time. As a consequence, only light leucocytic diapedesis was apparent (L). The connective tissue of this ear chamber is remarkably clear of $\mathrm{PMNG}$ at this stage of the reaction. Compare with Fig. $1 . \times 200$. Fig. 5. Hyperglycemic acidotic rabbit. Same area as Fig. 4 but $9 \mathrm{hr}$ after injury. The exudation of PMNG (L) failed to approach that observed in ear chambers of untreated rabbits followed for same length of time (compare with Fig. 2). Sticking of cells (S) could be seen but again was temporary and accompanied by only light diapedesis. $\times 200$. Fig. 6 . Hyperglycemic acidotic rabbit. Note the paucity of PMNG (L) found in burned tissue $24 \mathrm{hr}$ post injury in treated animals. No leucocytic sticking was seen. This was in striking contrast with the heavy exudate found in chambers of untreated animals at $24 \mathrm{hr}$ (See Fig. 3). $\times 400$.

FigURES 7 and 8 illustrate the lessened inflammatory reaction in glucose THAM infused rabbits with hyperglycemia and hyperosmolality uncomplicated by acidosis. Fig. 7. Hyperglycemic rabbit. Hyperosmolality without acidosis. The inflammatory response was less than controls $2 \mathrm{hr}$ postinjury. Light sticking of PMNG can be seen (S), but it is substantially less than encountered in untreated animals. Arteriolar (A) and venular (V) stasis can be seen at edge of burn. Compare with Fig. 1 and Fig $4 . \times 200$. Fig. 8. Hyperglycemic rabbit. Hyperosmolality without acidosis. The response $4 \mathrm{hr}$ after injury showed light sticking (S) of PMNG and very little diapedesis (L). The connective tissue is essentially devoid of inflammatory cells at this time. $\times 200$. 
Thus, it was concluded that hyperglycemia and hyperosmolality were sufficient to depress the cellular aspects of acute inflammation.

\section{DISCUSSION}

It was concluded from the studies just described that the acute inflammatory reaction generated by heat injury was impaired in rabbits with the induced metabolic triad of hyperglycemia, hyperosmolality, and metabolic acidosis. In particular, the number of leucocytes and erythrocytes observed in the connective tissue of damaged ear chambers was decreased substantially after rabbits were given glucose continuously by vein for $4 \mathrm{hr}$ and for 24 $\mathrm{hr}$. This reduction in vigor of leucocytic exudation seemed directly related to the scant number of white blood cells that adhered to injured endothelium; whereas, there was no obvious explanation for the diminished number of extravascular red blood cells. It was observed previously that when erythrocytes were extruded from blood vessels, they traversed vascular endothelium via "holes" created by emigrating white blood cells (13). Thus a reduction in intensity of leucocytic diapedesis could account for the lessened perivascular hemorrhage found in these experiments.

It was tempting to attribute this suppression of inflammation to the elevated values of blood glucose. However, hypertonic infusions of glucose produced hyperosmolality of serum with uncompensated metabolic lactic acidosis. Further experiments revealed that when the acidosis was neutralized or prevented with THAM, the inflammatory response to burn injury was still impaired. Hence, hyperglycemia and hyperosmolality appeared to be a sufficient derangement for reducing the sticking capacity of leucocytes and their subsequent diapedesis after burn injury. This result may thus represent a highly significant fact when applied to the overall metabolic abnormality found in humans with poorly regulated diabetes mellitus. It is possible that elevated blood sugar levels may materially compromise the vigor of the leucocytic sticking reaction when these cells marginate as a consequence of injury. This turn of events may then reduce the number of diapedesing leucocytes and thereby effectively dampen the cellular reaction to inflammation. Enhancement of bacterial and fungal infections might then result.

Considerable support may yet be marshaled for the concept that excesses of plasma or tissue osmolality or hydrogen ion concentration bear directly upon the vigor and effectiveness of the host immune mechanism. Studies conducted in a fluid medium have shown repeatedly that extremes of osmolality can depress not only phagocytic activity $(14,15)$ but also the capacity for PMNG to clump together into aggregates after ingestion of bac- teria has taken place (16). Evidence of this sort leads one to suspect that hyperglycemia with modest elevations of serum and tissue osmolality may have a significant influence upon the host defense mechanism against infection. In this regard it is likely that the net electrical charge of the formed elements is responsible for their stable dispersion in the circulation. Conditions that alter this charge, such as rather subtle changes of osmolality or hydrogen ion concentration, might be expected to modify profoundly the capacity of these elements to respond to injurious stimuli in the usual manner. Finally, it should be pointed out that since the alterations of osmolality were not comparable to the high levels that have been used (16) to change leucocytic adhesiveness in vitro one cannot exclude completely the nonosmotic effect of glucose.

\section{ACKNOWLEDGMENTS}

This study was supported by Research Grants HE-02792, A1-00290, 5-T01-AI00379-01, and A1-69 from the National Institutes of Health.

\section{REFERENCES}

1. Andriole, V. T., and H. F. Hasenclever. 1962-63. Factors influencing experimental candidiasis in mice. I. Alloxan diabetes. Yale J. Biol. Med. 35: 96.

2. Drachman, R. H., R. K. Root, and W. B. Wood, Jr. 1966. Studies on the effect of experimental nonketotic diabetes mellitus on antibacterial defense. I. Demonstration of a defect in phagocytosis. J. Exp. Med. 124: 227.

3. Sheldon, W. H., and H. Bauer. 1959. The development of the acute inflammatory response to experimental cutaneous murcormycosis in normal and diabetic rabbits. J. Exp. Med. 110: 845.

4. Perillie, P. E., J. P. Nolan, and S. C. Finch. 1962. Studies of the resistance to infection in diabetes mellitus: local exudative cellular response. J. Lab. Clin. Med. 59: 1008 .

5. Bybee, J. D., and D. E. Rogers. 1964. The phagocytic activity of polymorphonuclear leucocytes obtained from patients with diabetes mellitus. J. Lab. Clin. Med. 64: 1 .

6. Briscoe, H. F., and F. Allison, Jr. 1965. Diabetes and host resistance. I. Effect of alloxan diabetes upon the phagocytic and bactericidal efficiency of rat leukocytes for pneumococcus. J. Bacteriol. 90: 1537.

7. Crosby, B., and F. Allison, Jr. 1966. Phagocytic and bactericidal capacity of polymorphonuclear leucocytes recovered from venous blood of human beings. Proc. Soc. Exp. Biol. Med. 123: 660.

8. Rocha, H., and F. R. Fekety, Jr. 1964. Acute inflammation in the renal cortex and medulla following thermal injury. J. Exp. Med. 119: 131.

9. Barger, A. C. 1965. Cortical and medullary blood flow in the kidney. In Progress in Pyelonephritis. E. H. Kass, editor. F. A. Davis Co., Philadelphia. 398-407.

10. Andriole, V. T., and F. H. Epstein. 1965. Prevention of pyelonephritis by water diuresis: evidence for the role 
of medullary hypertonicity in promoting renal infection. J. Clin. Invest. $44: 73$.

11. Wells, C. H., T. P. Bond, and M. M. Guest. 1965. Changes in capillary blood flow induced by the extravascular application of hypertonic solutions: a possible mechanism for the control of renal medullary blood flow. Tex. Rep. Biol. Med. 23: 128.

12. Cruickshank, A. H. 1954. Resistance to infection in the alloxan-diabetic rabbit. J. Pathol. Bacteriol. $67: 323$.

13. Allison, F., Jr., M. R. Smith, and W. B. Wood, Jr. 1955. Studies on the pathogenesis of acute inflammation. I.
The inflammatory reaction to thermal injury as observed in the rabbit ear chamber. J. Exp. Med. 102: 655 .

14. Chernew, I., and A. Braude. 1962. Depression of phagocytosis by solutes in concentrations found in the kidney and urine. J. Clin. Invest. 41: 1945.

15. Sbarra, A. J., W. Shirley, and J. S. Baumstark. 1963. Effect of osmolarity on phagocytosis. J. Bacteriol. 85: 306.

16. Allison, F., Jr., and M. G. Lancaster. 1965. Pathogenesis of acute inflammation. VI. Influence of osmolarity and certain metabolic antagonists upon phagocytosis and ad. hesiveness by leucocytes recovered from man. Proc. Soc. Exp. Biol. Med. 119: 56. 